\title{
High-Throughput Assay of Levansucrase Variants in Search of Feasible Catalysts for the Synthesis of Fructooligosaccharides and Levan
}

\author{
Karin Mardo ${ }^{1}$, Triinu Visnapuu ${ }^{1}$, Maria Gromkova ${ }^{1}$, Anneli Aasamets ${ }^{1}$, Katrin Viigand ${ }^{1}$, \\ Heiki Vija ${ }^{2}$ and Tiina Alamäe ${ }^{1, *}$
}

1 Department of Genetics, Institute of Molecular and Cell Biology, University of Tartu, Riia 23, 51010 Tartu, Estonia; E-Mails: kmardo@ut.ee (K.M); triinu.visnapuu@ut.ee (T.V.); manjunja@ut.ee (M.G.); anneli.aasamets@gmail.com(A.A); katrin66@ut.ee (K.V.)

2 National Institute of Chemical Physics and Biophysics, Akadeemia tee 23, 12618 Tallinn, Estonia; E-Mail: heiki.vija@kbfi.ee

* Author to whom correspondence should be addressed; E-Mail: talamae@ebc.ee; Tel.: +372-5-295-378; Fax: +372-7-420-286.

Received: 28 March 2014; in revised form: 10 June 2014 / Accepted: 10 June 2014 / Published: 20 June 2014

\begin{abstract}
Bacterial levansucrases polymerize fructose residues of sucrose to $\beta-2,6$ linked fructans - fructooligosaccharides (FOS) and levan. While $\beta$-2,1-linked FOS are widely recognized as prebiotics, the health-related effects of $\beta-2,6$ linked FOS are scarcely studied as they are not commercially available. Levansucrase Lsc3 (Lsc-3) of Pseudomonas syringae pv. tomato has very high catalytic activity and stability making it a promising biotechnological catalyst for FOS and levan synthesis. In this study we evaluate feasibility of several high-throughput methods for screening and preliminary characterization of levansucrases using 36 Lsc3 mutants as a test panel. Heterologously expressed and purified His-tagged levansucrase variants were studied for: (1) sucrose-splitting activity; (2) FOS production; (3) ability and kinetics of levan synthesis; (4) thermostability in a Thermofluor assay. Importantly, we show that sucrose-splitting activity as well as the ability to produce FOS can both be evaluated using permeabilized levansucrase-expressing E. coli transformants as catalysts. For the first time we demonstrate the key importance of Trp109, His113, Glu146 and Glu236 for the catalysis of Lsc3. Cost-effective and high-throughput methods presented here are applicable not only in the levansucrase assay, but have a potential to be adapted for high-throughput (automated) study of other enzymes.
\end{abstract}


Keywords: levansucrase; fructooligosaccharides; levan; Pseudomonas syringae; cell permeabilization; Thermofluor; prebiotics

\section{Introduction}

Levansucrases (EC 2.4.1.10) are bacterial extracellular enzymes that convert sucrose into $\beta$-2,6linked fructooligosaccharides (FOS) of varied chain length and high-molecular weight levan [1]. These enzymes are present in many plant-related bacteria such as Pseudomonas syringae [2-4], Gluconacetobacter diazotrophicus [5], Zymomonas mobilis [6] and Erwinia amylovora [7-9], but also in Bacillus subtilis, B. megaterium [10,11] and several lactic acid bacteria such as Lactobacillus sanfranciscensis, L. reuteri and Leuconostoc mesenteroides [12-14].

FOS which are derived from plant storage polysaccharide inulin (a $\beta-2,1$ linked fructan) are already widely recognized as prebiotics [15,16]. They are industrially produced from plant sources and used in various food- and health-related products. On the contrary, other types of FOS are not commercially available and therefore their biological effects are scarcely studied. Still, a few papers, for example [17], report that $\beta$-2,6-linked (levan-type) FOS are selectively fermented by bifidobacteria showing even stronger prebiotic effects than their $\beta-2,1$ linked counterparts. Neokestose, a fructosylglucosylfructoside produced from sucrose by a fungus Xanthophyllomyces dendrorhous, also showed a bifidogenic effect on human gut microbiota [18]. Notably, a recent paper by Marsh and coworkers states that water kefir grains originating from different regions of the world contain Z. mobilis as main bacterial component [19]. As Z. mobilis possesses a levansucrase, water kefir, a popular healthy drink produced by fermentation of sucrose-containing water with water kefir grains as a starter, most likely contains levan and FOS. The prebiotic effect of polymeric fructans (inulin and levan) on lactobacilli and bifidobacteria is most probably assisted by other bacteria in the gut that degrade these large molecules to oligomers. For further study of the physiological effects of $\beta$-2,6-linked FOS and levan, biotechnologically feasible production systems applying wild-type enzymes or selected mutant variants should be established.

We have cloned and heterologously expressed three genomic levansucrase genes $l s c 1$, $l s c 2$ and $l s c 3$ (also designated as $l s c-1, l s c-2$ and $l s c-3$ ) from a plant pathogen, Pseudomonas syringae pv. tomato [4]. The respective proteins have highly similar sequences and general catalytic properties $[4,20]$. We have shown that purified Lsc3 protein has a very high catalytic constant $\left(\mathrm{k}_{\mathrm{cat}} 504.41 / \mathrm{s}\right)$ [21]. A higher $\mathrm{k}_{\mathrm{cat}}$ (2272 1/s) has been recorded only for the levansucrase of $B$. megaterium [11] whereas levansucrases of G. diazotrophicus and Z. mobilis have eight and 18 times lower $\mathrm{k}_{\text {cat }}$ values than Lsc3, respectively [5,6]. Lsc3 is a very efficient polymerizer, producing two types of fructans from sucrose: high-molecular weight levan and short-chain FOS $[21,22]$. The spectrum of FOS produced by Lsc3 is highly similar to that of a prebiotic inulin-type FOS mixture (P95 from Orafti, Beneo, Belgium) as verified using different analysis methods: thin layer chromatography (TLC), nanoelectrospray ionization mass spectrometry (nanoESI MS) [22] and high-performance liquid chromatography (HPLC) [23]. Importantly, Lsc3 transfructosylated eleven out of twelve nonconventional acceptor substrates tested by us. Among them, sorbitol, xylobiose, galacturonic acid, mannitol, xylitol and methyl-glucopyranoside were shown to serve as fructosyl acceptors for levansucrases for the first time [21]. 
In the search, isolation and characterization of levansucrase mutants, we have elaborated and applied several high-throughput methods. Firstly, for the selection of random mutants of the Lsc3 protein, we introduced a microplate-based assay of levansucrase activity on permeabilized cells of levansucrase-expressing $E$. coli as a catalyst. This method was further applied for preliminary study of site-directedly mutated Lsc3 variants [21]. As the majority (88\%) of levansucrase activity was detected in the cytoplasmic fraction of levansucrase-expressing E. coli and only $12 \%$ in the periplasm [4], permeabilization is needed to disclose also the activity of the cytoplasmic fraction of the protein [20]. Secondly, we introduced a microplate-based assay of levan production kinetics to characterize polymerization ability of the Lsc3 mutants [21]. Thirdly, for the first time we applied NanoMate robot-assisted electrospray ionization coupled with high-capacity ion trap mass spectrometry for the analysis of Lsc3-produced homo- and heterooligofructans in underivatized form [21,22].

In the current work we introduced a set of high-throughput and cost-saving methods feasible for levansucrase assay. These methods were evaluated on a panel of random and site-specifically constructed Lsc3 mutants. Several of these mutants have been described earlier, but novel variants were also included. The wild-type Lsc3 was be used as a reference. We assayed following biochemical properties of the purified levansucrases: (1) sucrose-splitting activity, also referred to as total activity; (2) the amount and spectrum of FOS produced; (3) ability and kinetics of levan synthesis; (4) thermal stability of levansucrases. In addition, we evaluated some of these characteristics using permeabilized cells of levansucrase-expressing E. coli as catalysts. The results retrieved from high-throughput assays were compared with those obtained by using conventional more laborious methods.

\section{Results and Discussion}

\subsection{The Lsc3 Mutants Used in This Study}

Lsc3 variants addressed in the study include the wild-type Lsc3 and its thirty six mutants. Twenty two of them were previously characterized by us. Among those are the inactive mutants of the catalytic triad Asp62Ala, Asp219Ala and Glu303Ala [23], mutants with significantly decreased polymerizing ability (Thr302Pro, Gln301Ala and substitution mutants of His321 with Arg, Leu, Lys or Ser) [21,23], mutants Trp61Ala, Trp61Asn, Arg304Cys and Arg304Ala which are strongly hampered in sucrose-splitting as well as polymerization abilities [23] and some others exhibiting moderate changes compared to the wild-type Lsc3. Fourteen mutants of Lsc3 are described here for the first time. Among those are so-called "Yanase mutants". Inspired by a superior paper by Yanase et al. [6] on mutational analysis of the Zymomonas mobilis levansucrase (LevU), we constructed homologues of Trp80Arg, Glu117Gln, Glu211Gln, Val223Ala and Asp308Asn mutants of Z. mobilis enzyme. Corresponding mutants of Lsc3 are Trp109Arg, Glu146Gln, Glu236Gln, Val248Ala and Asp333Asn. To gain more information on the functions of these positions, some additional substitutions were made. Therefore, Trp109 in Lsc3 was also replaced with Ala and Phe, and Asp333 with Ala. Several novel mutants of Lsc3 studied here originate from random mutagenesis, the method of which was described by us earlier [21]. All Lsc3 variants addressed in this work and respective mutagenic oligonucleotides are listed in Supplementary Table S1. Mutant variants are also designated in Figure 1 above the alignment 
of the levansucrases. The mutant $l s c 3$ genes were cloned into pURI3 vector for overexpression in E. coli as N-terminally $\mathrm{His}_{6}$-tagged fusion proteins ([24,25]; see Sections 3.1 and 3.2).

Figure 1. Lsc3 mutants with substituted positions designated as \# above the MUSCLE [26] alignment of levansucrases from Pseudomonas syringae pv. tomato (Lsc3), Erwinia amylovora, Rahnella aquatilis, Zymomonas mobilis, Pseudomonas chrororaphis subsp. aurantiaca, Gluconacetobacter diazotrophicus and Bacillus subtilis.

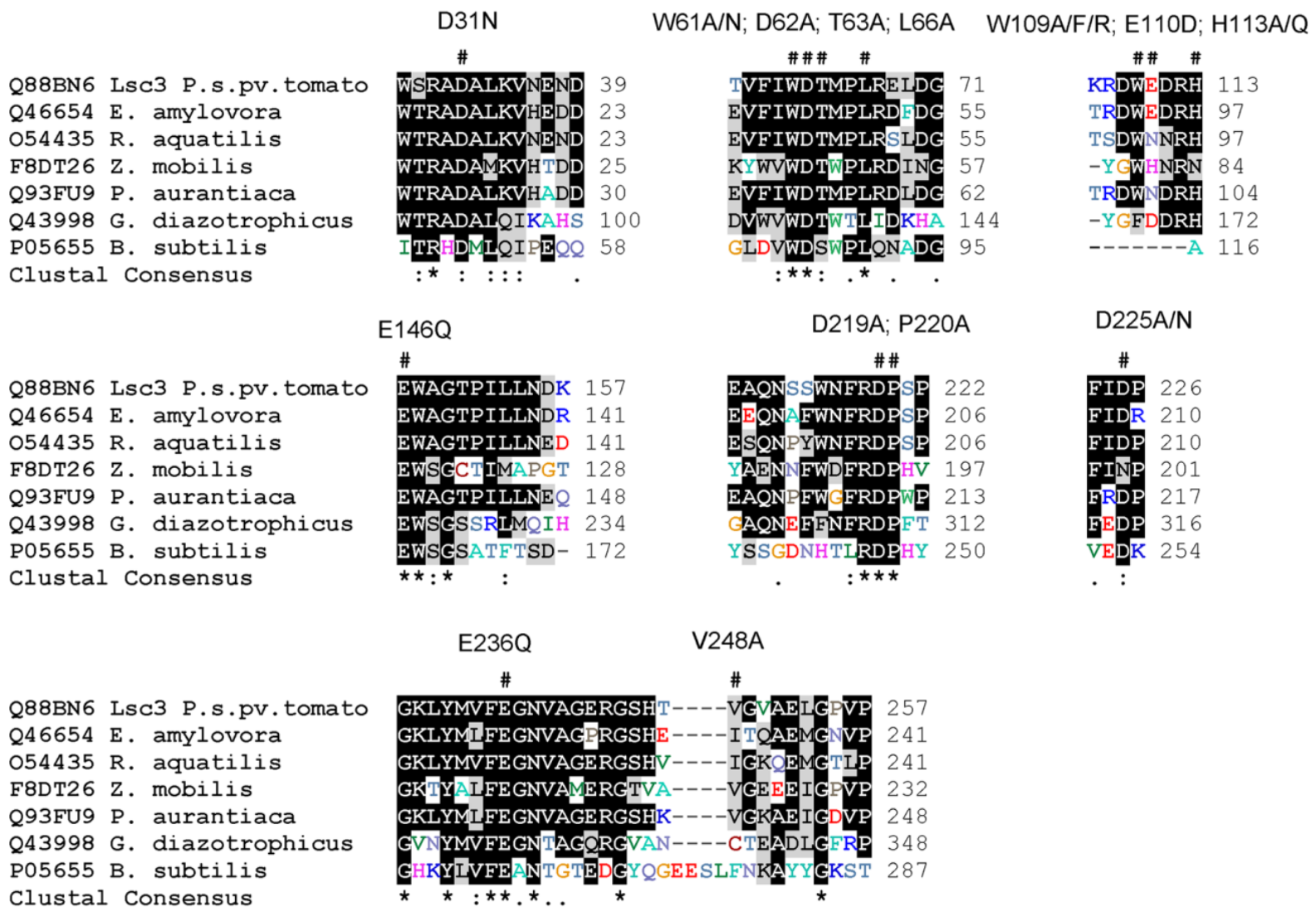

D300A/N; Q301A/E; T302P/M; E303A/Q; R304A/C; H306A;

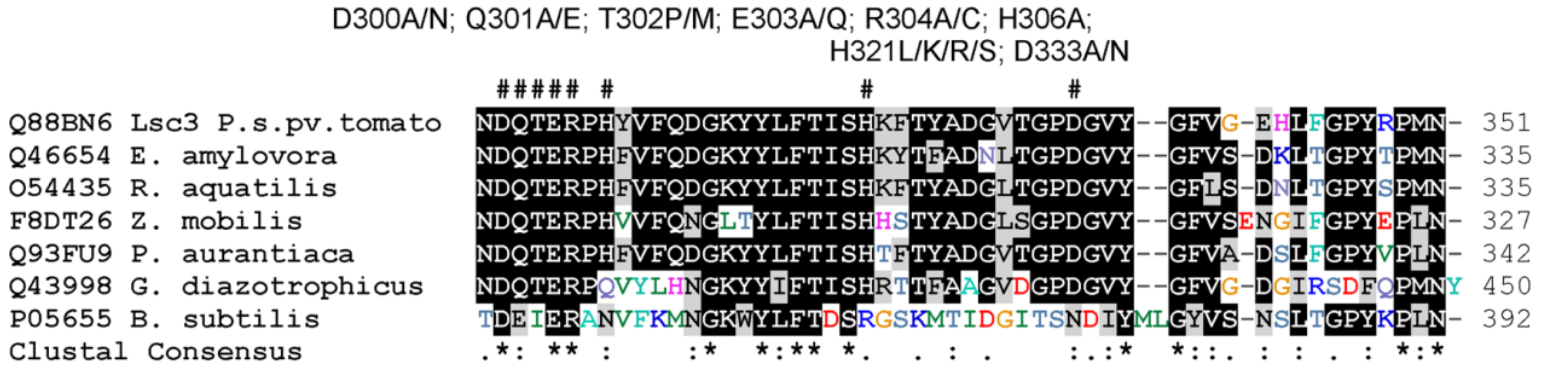

Figure 2 shows the location of amino acids equivalent to Trp109, His113 and Glu236 of Lsc3 on a 3D model of $G$. diazotrophicus enzyme LsdA. Trp109 and Glu236 correspond to Trp80 and Glu211 in Z. mobilis levansucrase (Figure 1). The Glu211Gln mutant showed vastly reduced polymerizing ability and Trp80Arg mutant was unable to synthesize polymeric levan [6]. As we show in this study, mutation of His113 in Lsc3 (we studied His113Gln and His113Ala substitutions) has a strong negative effect on the catalysis (Section 2.3; for further discussion see Section 2.7). The importance of the above-mentioned positions can be predicted from the location of respective residues in the substrate-binding pocket (Figure 2). 
Figure 2. Catalytic centre of G. diazotrophicus levansucrase LsdA (PDB ID: 1W18; [5]) with side chains of catalytic triad residues (Asp135, Asp309 and Glu401) indicated in blue. The structure of the protein was visualized using PyMol [27]. Raffinose (consisting of galactose, glucose and fructose residues) shown in substrate-binding pocket originates from the structure of the B. subtilis levansucrase SacB in complex with raffinose (PDB ID: 3BYN) that was superimposed with the LsdA structure. Positions of LsdA equivalent to Trp109, His113 and Glu236 of Lsc3 of P. syringae pv. tomato are shown on the model. Respective amino acids of levansucrases of different bacteria are shown in different colour: LevU of $Z$. mobilis (black), Lsc3 of $P$. syringae pv. tomato (red) and LsdA of G. diazotrophicus (green and blue).

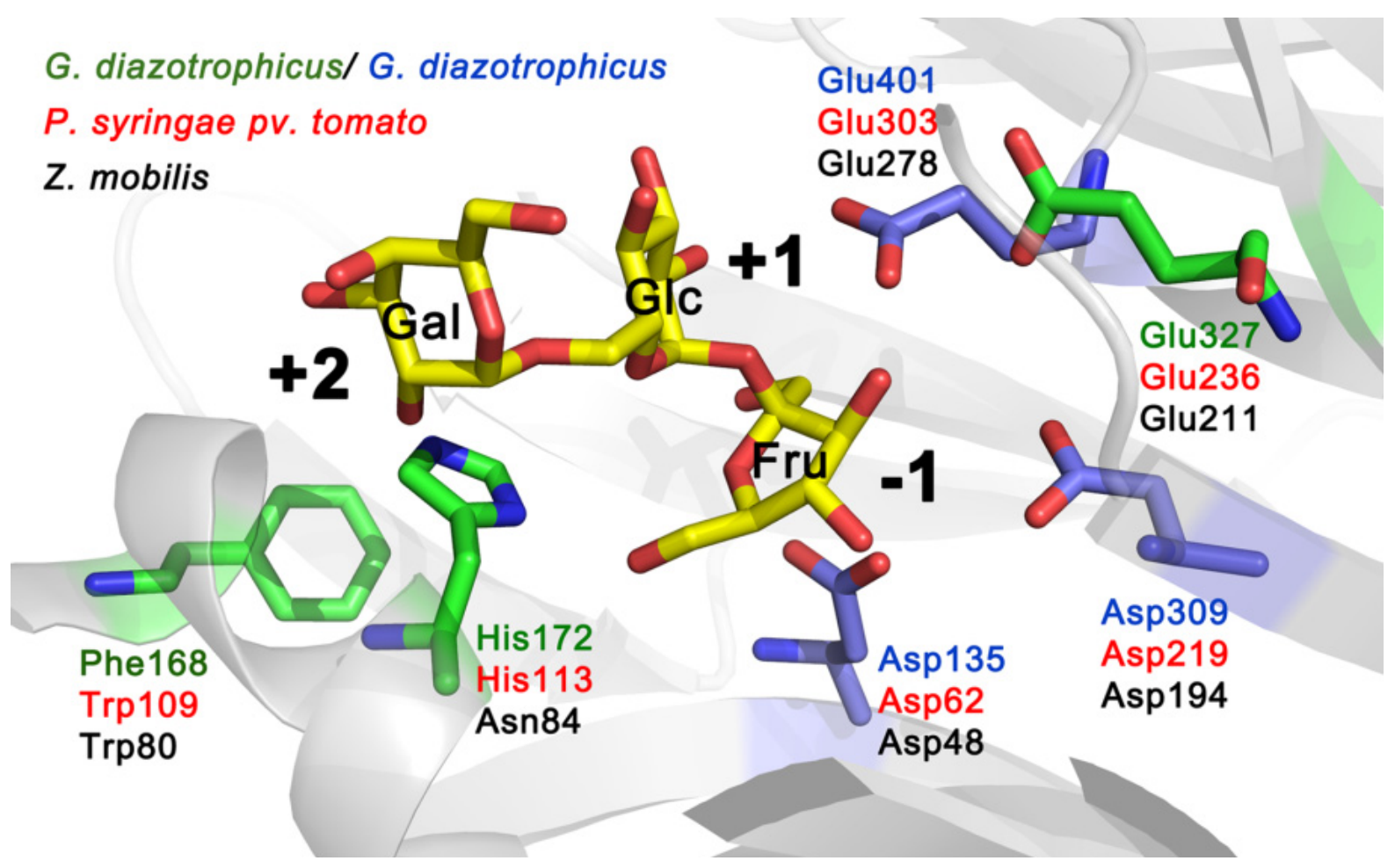

\subsection{The Simplest Way to Detect Levansucrase Activity-Assay of the Growth Phenotype of} Levansucrase-Expressing Bacteria on Agar Plate Containing Sucrose

Levansucrase-possessing bacteria have mucoid colonies when grown on sucrose-containing agar plate due to the synthesis of levan. This feature can be used to detect and identify bacteria that produce a levansucrase, but also to select levansucrase mutants through heterologous expression in E. coli [6,20,28]. We have used this simple and informative method in the cloning of $l s c 1, l s c 2$ and $l s c 3$ genes of $P$. syringae pv. tomato [4] and selection of random mutants of the Lsc3 protein [21]. Figure 3 shows growth phenotype of E. coli transformants expressing wild-type Lsc3 and its catalytic triad mutants growing on MacConkey medium containing 10\% sucrose. Only wild-type Lsc3 produces levan giving a mucoid phenotype to the streaks of respective transformant. Also, only in case of wild-type Lsc3 expression, acidification of the medium (pink colour around the streak) due to sugar fermentation is visible. 
Figure 3. Levan synthesis phenotype of E. coli BL21(DE3) expressing wild-type Lsc3 and alanine replacement mutants of the catalytic triad amino acids. Transformants were streaked onto MacConkey + Amp medium containing 10\% sucrose and $1 \mathrm{mM}$ IPTG to induce the $\mathrm{T} 7$ polymerase and grown at $37{ }^{\circ} \mathrm{C}$ (see Section 3.2).

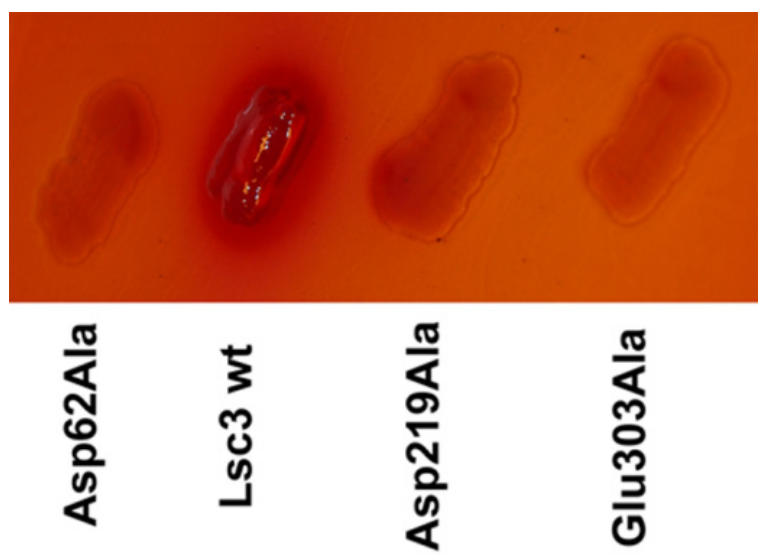

\subsection{Total Levansucrase Activity Can Be Reliably Measured on Microplates not only Using Purified} Proteins, but also Implementing Permeabilized E. coli Transformants as Catalysts

Most often, enzyme activities are measured by performing reactions in a volume of $1-2 \mathrm{~mL}$. This approach needs a high amount of protein and chemicals and is usually quite time-consuming and costly. Microplate-aided assays save time, money and can be robotized. Total activity of levansucrases is traditionally evaluated according to the velocity of sucrose-splitting reaction. This reaction is required for both sucrose hydrolysis as well as transfructosylation reaction. Each act of sucrose splitting releases a glucose molecule that can be quantified in several ways. We have been using the Glucose liquicolor assay. As described by the manufacturer (Human GmbH, Wiesbaden, Germany), this procedure relies on oxidation of glucose by glucose oxidase, yielding hydrogen peroxide which reacts under catalysis of peroxidase with phenol and 4-aminophenazone to yield a reddish quinoneimine product, concentration of which is measured at $500 \mathrm{~nm}$. We routinely determine kinetic constants of sucrosesplitting reaction of levansucrases by performing reaction in Eppendorf tubes with $1 \mathrm{~mL}$ volume of reaction mixture. At fixed time points, small samples are withdrawn for the estimation of liberated glucose. We have earlier used this approach to determine the $\mathrm{K}_{\mathrm{m}}$ and $\mathrm{V}_{\max }$ values of sucrose-splitting reaction of levansucrases [4,21,23] and applied the same method here (see Section 3.8). Using a set of 36 Lsc3 mutants with largely varied catalytic activity, we show here that sucrose-splitting activity of the levansucrases can be reliably measured in a high-throughput way, i.e., on microplates. Moreover, we demonstrate that sucrose splitting by a levansucrase can also be evaluated on the permeabilized E. coli transformants expressing respective protein. Figure 4 compares the results obtained by these two methods. One can see that they correlate fairly well. Our levansucrase assay on permeabilized E. coli transformants presumes similar expression level for different Lsc3 variants in the host. Therefore, all induced E. coli cultures subjected to levansucrase activity assay were studied for levansucrase expression and similar expression levels for different levansucrase variants were detected. From every induced culture, equal amounts were analysed by SDS-PAGE and the intensity 
of the bands corresponding to levansucrase protein was compared after staining of the gels with Coomassie Brilliant Blue (data not shown).

Figure 4. Quantitative evaluation of the sucrose-splitting (total) levansucrase activity on microplates. Either CTAB-permeabilized E. coli transformants expressing a certain Lsc3 variant (upper panel) or respective purified proteins (lower panel) were used as catalysts. Respective methods are described in Sections 3.3 and 3.4. Mutants of catalytic triad positions are designated in green and Lsc3 mutants studied for the first time in red. Mutant Glu303Gln falls into both categories. The activities of mutant enzymes are expressed as percentage of respective value of wild-type Lsc3 taken as 100\% (grey lines). Total activity of purified wild-type Lsc3 protein was $461.6 \pm 95.5 \mathrm{U} / \mathrm{mg}$. In the assay on permeabilized cells, the absorption values at $500 \mathrm{~nm}$ indicating glucose concentration were normalized to cell suspension densities and the value obtained for wild-type Lsc3 was taken as $100 \%$. At least three parallel measurements for each levansucrase variant were made and mean values with respective standard deviations are shown.

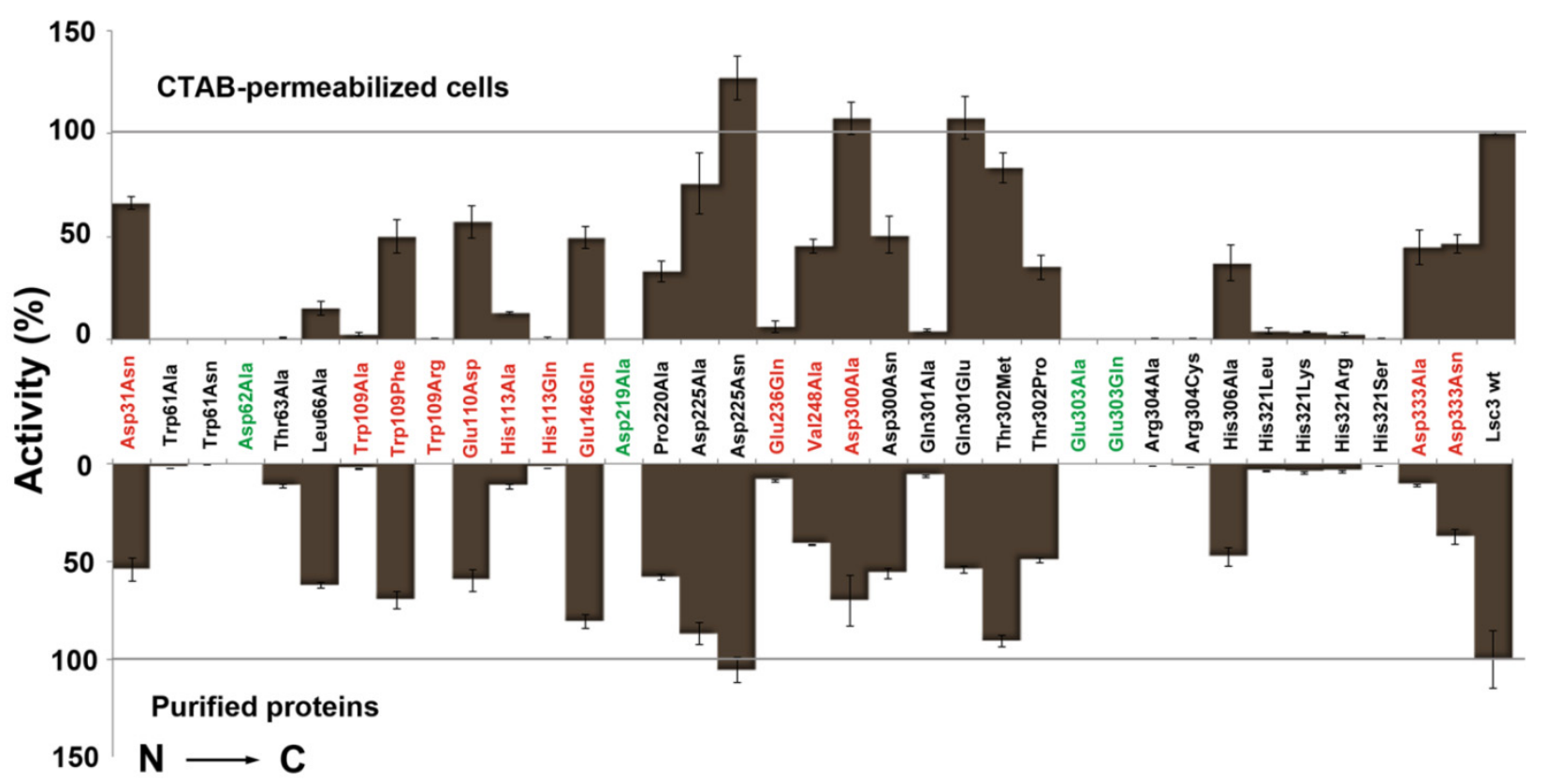

To permeabilize the $E$. coli cells, we used $0.1 \%$ cetyltrimethylammonium bromide (CTAB) (Section 3.3) that has only minimal activity-reducing effect on levansucrases. Notably, we have earlier used this surfactant not only for levansucrase activity assay on recombinant E. coli [23], but also to evaluate activities of maltase, $\beta$-glucuronidase and enzymes of methanol oxidation in yeast cell suspensions [29,30]. Earlier, de Abreu et al. [31] described a high-throughput microplate assay of Schwanniomyces occidentalis $\beta$-fructofuranosidase mutants. Gene library of respective genes was expressed in an invertase-negative mutant of Saccharomyces cerevisiae to reveal the protein variants with enhanced transfructosylation ability [31]. In that case, permeabilization of the yeast cells was not required as invertase is a cell surface-bound protein.

Figure 4 indicates that even a simple levansucrase activity assay on permeabilized $E$. coli clearly discloses catalytically disabled mutants Trp61Ala, Trp61Asn, Asp62Ala, Asp219Ala, Glu303Ala, Glu303Gln, Arg304Ala, Arg304Cys, His321Arg, His321Leu, His321Lys and His321Ser [21,23]. 
Concerning novel mutants, Trp109Ala, Trp109Arg, His113Gln and Glu236Gln stick out as the variants with significantly reduced sucrose-splitting ability. For comparison, $V_{\max }$ values of the sucrose-splitting reaction determined with purified proteins are presented in Figure 5. Some Lsc3 mutants, for example Glu236Gln and substitution mutants of His321, have highly reduced affinity for sucrose (Table 1). In consequence of that, the sucrose-splitting ability of these mutants is somewhat underestimated in microplate assay which was conducted with $100 \mathrm{mM}$ sucrose (Figure 4, Table 1).

Table 1. Affinity $\left(K_{m}\right)$ for sucrose and polymerizing properties of Lsc3 and its mutants. $K_{m}$ and TA were determined as described in Section 3.8 and the reaction products were analysed by HPLC (Section 3.9). The degree of polymerization (DP) of detected FOS is also presented. Reactions were performed either with purified proteins (see Section 3.6) or permeabilized cells of levansucrase-expressing E. coli (see Section 3.5). In the TA assay, $100 \%$ corresponds to the hypothetic situation where no free fructose is produced as a reaction product and all fructose residues of reacted sucrose molecules are incorporated into polymerization products FOS and levan. The mean values and standard deviation values of at least two independent experiments are shown.

\begin{tabular}{|c|c|c|c|}
\hline Levansucrase & $\mathbf{K}_{\mathrm{m}}(\mathbf{m M})$ & $\begin{array}{l}\text { Transfructosylation Activity (TA; \%) } \\
\text { Permeabilized Cells/Purified Protein }\end{array}$ & $\begin{array}{c}\text { Degree of Polymerization (DP) } \\
\text { Permeabilized Cells/Purified Protein }\end{array}$ \\
\hline Lsc3 wt & $18.5 \pm 2.5$ & $71 \pm 1 / 74 \pm 1^{a}$ & $3-7 / 3-7^{\mathrm{a}}$ \\
\hline Asp31Asn & $14.9 \pm 4.6$ & $65 \pm 4 / 70 \pm 3$ & $3-6 / 3-6$ \\
\hline Trp61Ala & $143.4 \pm 6.1$ & $\mathrm{ND} / 69 \pm 1^{\mathrm{a}}$ & $\mathrm{ND} / 3-6^{\mathrm{a}}$ \\
\hline Trp61Asn & $869.3 \pm 104.0$ & $\mathrm{ND} / 51 \pm 1^{\mathrm{a}}$ & $\mathrm{ND} / 3-4^{\mathrm{a}}$ \\
\hline Asp62Ala & $20.7 \pm 2.1$ & $\mathrm{ND} / \mathrm{ND}$ & $\mathrm{ND} / \mathrm{ND}$ \\
\hline Thr63Ala & $15.9 \pm 1.8$ & $75 \pm 3 / 71 \pm 3^{a}$ & $3-6 / 3-7^{\mathrm{a}}$ \\
\hline Leu66Ala & $27.3 \pm 4.2$ & $69 \pm 4 / 73 \pm 2^{a}$ & $3-6 / 3-7^{\mathrm{a}}$ \\
\hline Trp109Ala & $29.8 \pm 3.3$ & $72 \pm 6 / 77 \pm 1$ & $3-5 / 3-7$ \\
\hline Trp109Phe & $9.6 \pm 0.6$ & $62 \pm 3 / 74 \pm 1$ & $3-7 / 3-7$ \\
\hline Trp109Arg & $249.1 \pm 38.5$ & $\mathrm{ND} / 40 \pm 1$ & $\mathrm{ND} / 3$ \\
\hline Glu110Asp & $57.6 \pm 9.7$ & $57 \pm 4 / 70 \pm 1$ & $3-7 / 3-7$ \\
\hline His113Ala & $170.4 \pm 17.0$ & $43 \pm 1 / 41 \pm 6$ & $3-5 / 3-6$ \\
\hline His113Gln & $190.1 \pm 28.3$ & $65 \pm 5 / 51 \pm 3$ & $3-5 / 3-6$ \\
\hline Glu146Gln & $40.6 \pm 5.0$ & $63 \pm 5 / 76 \pm 1$ & $3-6 / 3-6$ \\
\hline Asp219Ala & $43.4 \pm 10.2$ & $\mathrm{ND} / \mathrm{ND}$ & $\mathrm{ND} / \mathrm{ND}$ \\
\hline Pro220Ala & $23.9 \pm 2.3$ & $71 \pm 2 / 75 \pm 2^{a}$ & $3-6 / 3-6^{a}$ \\
\hline Asp225Ala & $13.7 \pm 1.2$ & $61 \pm 1 / 71 \pm 2^{a}$ & $3-6 / 3-7^{\mathrm{a}}$ \\
\hline Asp225Asn & $18.8 \pm 0.8$ & $57 \pm 2 / 71 \pm 2^{a}$ & $3-6 / 3-7^{\mathrm{a}}$ \\
\hline Glu236Gln & $267.1 \pm 40.2$ & $46 \pm 1 / 50 \pm 4$ & $3-5 / 3-6$ \\
\hline Val248Ala & $14.1 \pm 1.1$ & $63 \pm 2 / 72 \pm 1$ & $3-7 / 3-6$ \\
\hline Asp300Ala & $19.4 \pm 1.3$ & $53 \pm 4 / 58 \pm 1$ & $3-7 / 3-8$ \\
\hline Asp300Asn & $50.7 \pm 5.4$ & $52 \pm 2 / 60 \pm 1^{a}$ & $3-9 / 3-10^{a}$ \\
\hline Gln301Ala & $313.7 \pm 30.0$ & $24 \pm 5 / 24 \pm 1^{a}$ & $3-4 / 3-4^{a}$ \\
\hline
\end{tabular}


Table 1. Cont.

\begin{tabular}{cccc}
\hline Levansucrase & $\mathbf{K}_{\mathbf{m}}(\mathbf{m M})$ & $\begin{array}{c}\text { Transfructosylation Activity (TA; } \%) \\
\text { Permeabilized Cells/Purified Protein }\end{array}$ & $\begin{array}{c}\text { Degree of Polymerization (DP) } \\
\text { Permeabilized Cells/Purified Protein }\end{array}$ \\
\hline Gln301Glu & $23.6 \pm 1.7$ & $34 \pm 8 / 45 \pm 1^{\mathrm{a}}$ & $3-5 / 3-5^{\mathrm{a}}$ \\
Thr302Met & $15.1 \pm 1.8$ & $56 \pm 1 / 70 \pm 1^{\mathrm{a}}$ & $3-6 / 3-6^{\mathrm{a}}$ \\
Thr302Pro & $42.5 \pm 6.7$ & $39 \pm 5 / 52 \pm 5^{\mathrm{a}}$ & $3-6 / 3-6^{\mathrm{a}}$ \\
Glu303Ala & $27.1 \pm 5.5$ & $\mathrm{ND} / \mathrm{ND}$ & $\mathrm{ND} / \mathrm{ND}$ \\
Glu303Gln & $129.6 \pm 9.6$ & $\mathrm{ND} / \mathrm{ND}$ & $\mathrm{ND} / \mathrm{ND}$ \\
Arg304Ala & $66.0 \pm 9.8$ & $\mathrm{ND} / 70 \pm 2^{\mathrm{a}}$ & $\mathrm{ND} / 3-6^{\mathrm{a}}$ \\
Arg304Cys & $12.5 \pm 1.1$ & $\mathrm{ND} / 69 \pm 1^{\mathrm{a}}$ & $\mathrm{ND} / 3-4^{\mathrm{a}}$ \\
His306Ala & $21.2 \pm 2.4$ & $70 \pm 5 / 72 \pm 1^{\mathrm{a}}$ & $3-7 / 3-7^{\mathrm{a}}$ \\
His321Leu & $352.1 \pm 41.7$ & $17 \pm 1 / 20 \pm 5$ & $3 / 3$ \\
His321Lys & $529.5 \pm 68.3$ & $30 \pm 1 / 27 \pm 2$ & $3-4 / 3-4$ \\
His321Arg & $451.0 \pm 36.8$ & $36 \pm 1 / 25 \pm 1$ & $3 / 3-4$ \\
His321Ser & $503.3 \pm 87.8$ & $31 \pm 4 / 23 \pm 3$ & $3-4 / 3-4$ \\
Asp333Ala & $27.0 \pm 2.9$ & $65 \pm 3 / 68 \pm 1$ & $3-5 / 3-5$ \\
Asp333Asn & $41.3 \pm 4.2$ & $67 \pm 3 / 80 \pm 1$ & $3-7 / 3-7$ \\
\hline
\end{tabular}

${ }^{a}$ data from Ref. [23]; ND—not detected; value under detection limit.

\subsection{The Ability of FOS Production by Levansucrases Can be Evaluated on Microplates}

Production of $\beta-2,6$ linked FOS is important because of their potential biological (prebiotic) effects. They are not produced commercially and are therefore practically impossible to purchase. The $\beta-2,6$ linked FOS have been produced for prebiotic efficiency studies in small amounts by controlled chemical hydrolysis of bacterial levan and isolation of the oligosaccharide fractions [17]. However, some levansucrases, for example LsdA of G. diazotrophicus, produce mostly short-chain products from sucrose and only a low amount of levan [32-34]. Levansucrases with this ability are potential catalysts for large-scale synthesis of $\beta-2,6$ linked FOS. We showed that Lsc3 protein of $P$. syringae pv. tomato is capable of FOS synthesis from sucrose, raffinose and sugar beet molasses. A high substrate concentration (600 $\mathrm{mM}$ and higher) and prolonged reaction time are required for FOS synthesis [22,23]. In the search of FOS-producing levansucrases, high-throughput methods for the analysis are preferred. We show here that the ability of levansucrases to produce FOS can be evaluated on microplates. Moreover, even permeabilized E. coli culture expressing a levansucrase can be reliably applied for FOS production assay (see Supplementary Figure S1). Indeed, if a levansucrase-expressing E. coli was permeabilized by $0.1 \% \mathrm{CTAB}$ and incubated on a microplate in buffer with $1 \mathrm{M}$ of sucrose for $20 \mathrm{~h}$, FOS were produced. The FOS spectrum characteristic for Lsc3 variants of our panel was determined by HPLC (see Section 3.9) and results are presented in Table 1. Respective spectra from reactions with purified proteins are given for comparison. Table 1 also shows transfructosylating activity (TA) of the levansucrases.

The liberation of glucose from a sucrose-splitting reaction shows the total levansucrase activity because glucose molecules are by-products of the reaction and are not polymerized. Fructosyl residues can be transferred to water, resulting in free fructose (hydrolytic activity) or to acceptor molecules other than water (sucrose and fructans), resulting in polymerization products such as FOS and levan (transfructosylating activity). The amount of free glucose and fructose in the reaction mixture is 
measured and TA is calculated according to the formula: $\left.\left([\mathrm{Glc}]-\left[\mathrm{Fru}_{\mathrm{F}}\right]\right) /[\mathrm{Glc}]\right) \times 100$, where $[\mathrm{Glc}]$ indicates the content of free glucose and $\left[\mathrm{Fru}_{\mathrm{F}}\right]$ the content of free fructose in the reaction mixture. Therefore TA indicates the percentage of fructosyl residues that levansucrase protein is using for transfructosylation [21]. Low TA value means that most of the fructosyl residues from splitted sucrose are transferred to water.

Table 1 shows that the size range of FOS produced can be detected by both high-throughput methods. For example, the Asp300Asn mutant stands out in both assays as the producer of FOS with extended chain length, up to degree of polymerization (DP) 9-10. The mutants synthesizing only short-chain FOS, with DP up to 4 (e.g., Gln301Ala and substitution mutants of His321) were also disclosed in both assays. In several cases, FOS production could not be detected in the assay on permeabilized transformants. In case of mutants with largely decreased catalytic activity, such as Trp61Ala, Trp61Asn, Trp109Arg, Arg304Ala and Arg304Cys (see activity data on Figure 4 and $V_{\max }$ data in Figure 5), FOS were detected only in reactions that were performed with an increased amount $(100 \mu \mathrm{g} / \mathrm{mL})$ of purified protein. Figure 5 shows data on total FOS production by Lsc3 variants per $1 \mathrm{mg}$ of pure protein.

Figure 5. The amount of total FOS ( $\mathrm{g} / \mathrm{mg}$ of protein) produced from $1.2 \mathrm{M}$ sucrose in a $20 \mathrm{~h}$ reaction by purified wild-type Lsc3 and thirty six mutant proteins. Mutants of catalytic triad positions are shown in green and the mutants studied in this work for the first time are in red. $\mathrm{V}_{\max }(\mathrm{U} / \mathrm{mg})$ of sucrose-splitting reaction is plotted for comparison. Mean values of at least two independent experiments are shown. Standard deviation was less than $15 \%$.

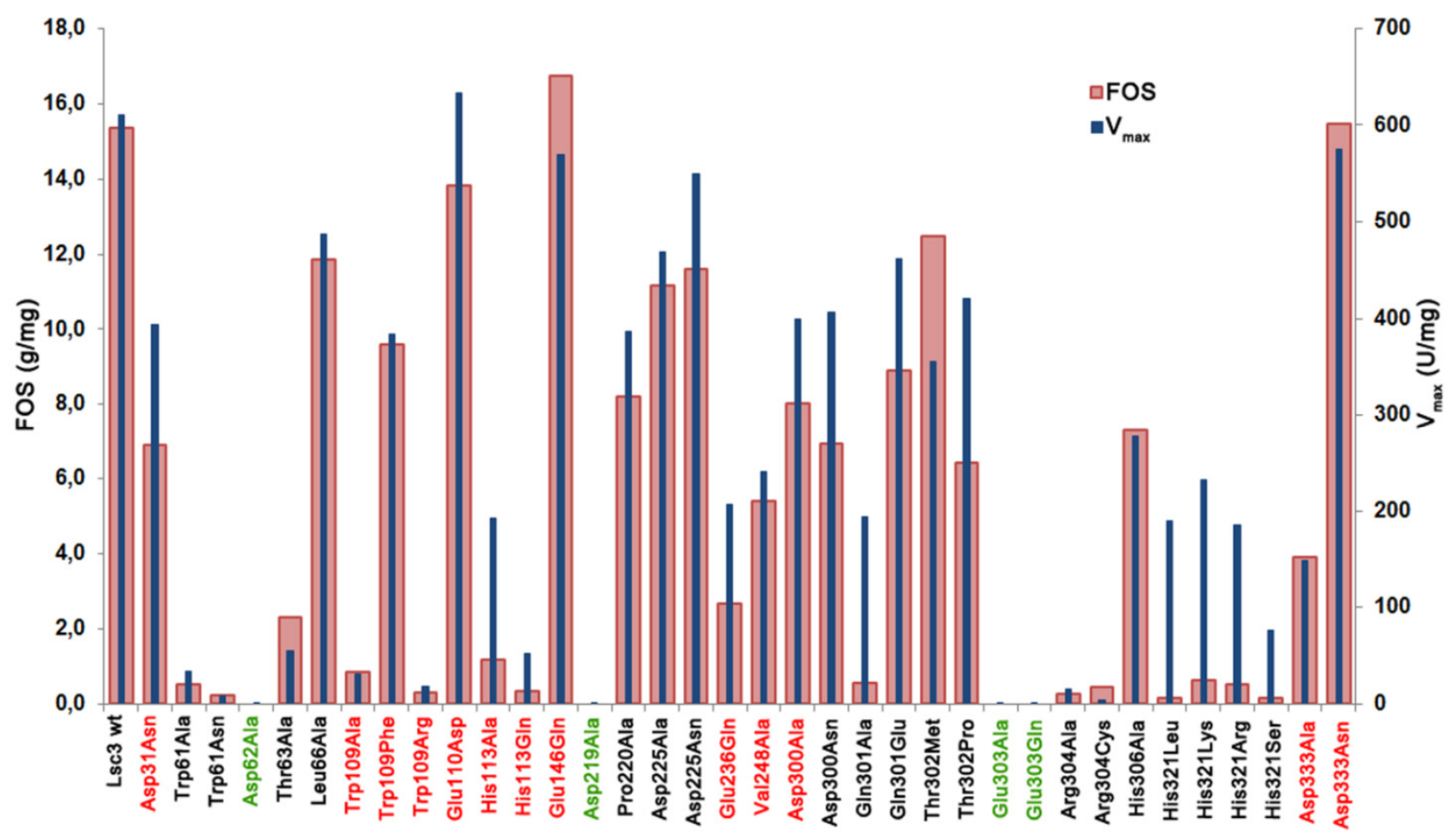

$\mathrm{V}_{\max }$ values of sucrose splitting for respective mutants are also included. Comparison of these two characteristics indicates that in case of mutants Asp31Asn, Glu110Asp, His113Ala, Glu236Gln, Asp300Ala, Asp300Asn, Gln301Ala, Thr302Pro and substitution mutants of His321 (His321Arg, 
His321Leu, His321Lys, His321Ser), FOS production is substantially more affected that the ability to split sucrose, meaning that these positions are specifically important for polymerization reaction. The mutants Glu146Gln, Thr302Met and Asp333Asn with fairly good sucrose-splitting activity and slightly enhanced FOS production (Figure 5) can be considered as promising candidates for enzymatic synthesis of FOS for biotechnological applications.

\subsection{Online Assay of Levan Synthesis Kinetics on a Microplate}

In this high-throughput procedure, the increase of turbidity due to levan formation is recorded online [21]. Here, we will present data on levan synthesis kinetics of fourteen novel Lsc3 mutants. Figure 6 shows that two mutants, Trp109Arg and Glu303Gln, do not produce levan. Glu303 is acid-base catalyst of Lsc3 [23] that explains behaviour of the Glu303Gln mutant. Retarded levan synthesis by Trp109Arg mutant was also expected as the equivalent mutant of $Z$. mobilis levansucrase (Trp80Arg) is also hampered in levan synthesis [6]. However, Trp109 replacement with Phe restored the ability for levan synthesis, achieving even increased production level of the fructan compared to wild-type Lsc3 (Figure 6). Levan production was very slow in case of mutants Trp109Ala, His113Ala, His113Gln and Glu236Gln. The Glu110Asp, Asp300Ala, Asp333Ala and Asp333Asn mutants were also somewhat hampered in levan synthesis (Figure 6).

Figure 6. Time course of levan synthesis by the wild-type Lsc3 protein (Lsc3 wt) and fourteen mutants. Reaction was conducted at $37^{\circ} \mathrm{C}$ on flat-bottom polystyrole microplates in total volume of $200 \mu \mathrm{L}$ per well. Reaction mixture contained $600 \mathrm{mM}$ of sucrose in McIllvaine's buffer ( $\mathrm{pH} 6.0$ ) and $10 \mu \mathrm{g} / \mathrm{mL}$ of purified protein. Increase of turbidity was measured at $400 \mathrm{~nm}$ every $15 \mathrm{~min}$ using Infinite M200 PRO microplate reader. Mean values of four parallel measurements are shown. Standard deviation was less than $10 \%$.

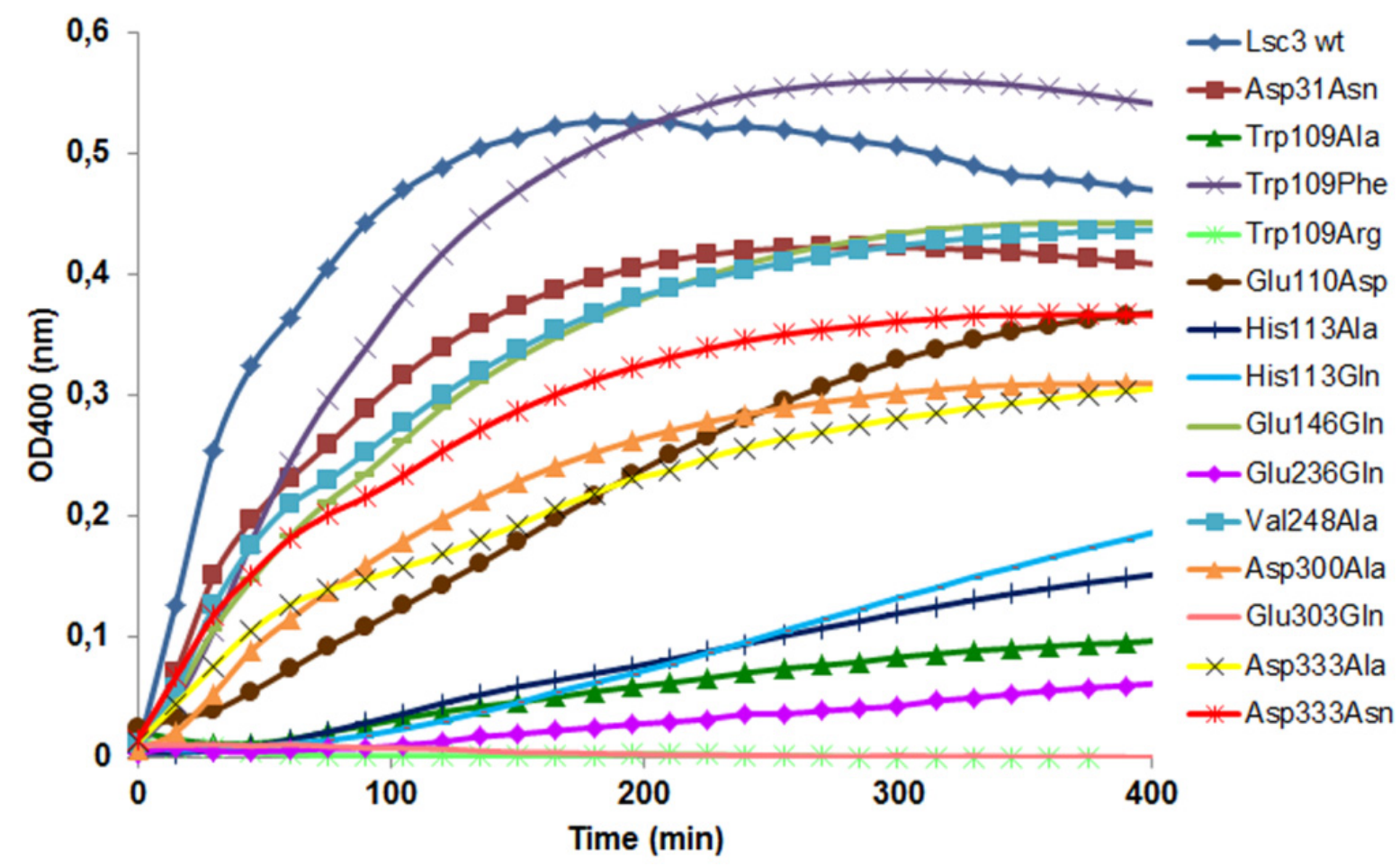


Figure 5 shows that substitution of Asp333 in Lsc3 does not specifically reduce FOS production. Yet, levan synthesis is significantly decreased even in case of Asp333Asn mutant which behaves quite similarly to the wild-type protein regarding the $\mathrm{V}_{\max }$ of sucrose-splitting reaction and FOS production (Figures 5 and 6). Thus Asp333 can be specifically important for prolongation of the fructosyl chain.

\subsection{Thermostability Assay of Levansucrases Using Two Different Approaches}

Enzymes applied in biotechnology should possess a high catalytic activity and long shelf-life. Bacterial extracellular proteins (including levansucrases) are suited for commercial applications as in nature they have to withstand harsh environmental conditions. We have shown earlier that Lsc3 protein has very high catalytic activity and long-term stability [21]. Previously we evaluated stability of the Lsc3 preparation during 30 days of storage at $37{ }^{\circ} \mathrm{C}$ in McIlvaine's buffer ( $\mathrm{pH}$ 6.0) with no loss of catalytic activity [21]. In our current study we further extended the storage time and report that during 140 days of incubation at $37{ }^{\circ} \mathrm{C}, \mathrm{Lsc} 3$ retained $50 \%$ of initial sucrose-splitting activity. If the same preparation was kept at $50{ }^{\circ} \mathrm{C}$, total catalytic activity dropped more rapidly-after 32 days the residual activity was only $6 \%$ of the initial activity. In current experiments, we kept the protein in $100 \mathrm{mM}$ MES buffer ( $\mathrm{pH}$ 6.5) supplemented with $150 \mathrm{mM} \mathrm{NaCl}$.

Thermofluor is a high-throughput method for protein characterization based on differential scanning fluorimetry [35]. In case of levansucrases, it has earlier been used for optimization of crystallization conditions of Erwinia amylovora levansucrase [8]. After having determined the optimal buffer conditions for wild-type Lsc3 we performed a Thermofluor assay on the panel of thirty seven levansucrase variants. The Thermofluor assay allows the determination of the melting temperature $\left(T_{m}\right)$ of the protein. Increase of temperature promotes unfolding of the protein and $T_{m}$ is defined as the midpoint of the unfolding transition. A shift in $\mathrm{T}_{\mathrm{m}}$ indicates a change in stability of the protein. The $\mathrm{T}_{\mathrm{m}}$ for Lsc3 according to Thermofluor assay was $65.4{ }^{\circ} \mathrm{C}$. The corresponding value of E. amylovora levansucrase was $57{ }^{\circ} \mathrm{C}$ and unfolding of this protein started at temperature above $45{ }^{\circ} \mathrm{C}$ [8]. In the assay, buffer conditions (100 mM HEPES buffer; pH 7.5 with $100 \mathrm{mM} \mathrm{NaCl}$ ) were slightly different than those of our assay. When we conducted the Thermofluor assay of Lsc3 in $100 \mathrm{mM}$ HEPES buffer ( $\mathrm{pH}$ 7.5), the $\mathrm{T}_{\mathrm{m}}$ value of it was only one degree lower than in $100 \mathrm{mM}$ MES buffer ( $\mathrm{pH}$ 6.5). Based on that we assume Lsc3 is substantially more thermostable than levansucrase of E. amylovora.

Most Lsc3 mutants had $\mathrm{T}_{\mathrm{m}}$ values close to the wild-type protein, ranging from 62 to $66^{\circ} \mathrm{C}$. The mutants Asp31Asn, Val248Ala and Thr302Pro had much lower $\mathrm{T}_{\mathrm{m}}$ than the wild-type Lsc3, whereas the mutant Thr302Met had enhanced stability - its $\mathrm{T}_{\mathrm{m}}$ was $67.5^{\circ} \mathrm{C}$. We then performed a traditional thermal inactivation assay with wild-type Lsc3 and the mutants Asp31Asn, Glu236Gln, Val248Ala, Thr302Met and Thr302Pro. The proteins were incubated in McIllvaine's buffer ( $\mathrm{pH} \mathrm{6.0)}$ for $30 \mathrm{~min}$ at a temperature ranging from 20 to $70{ }^{\circ} \mathrm{C}$, cooled on ice and residual total catalytic activity was determined by measuring release of glucose from $100 \mathrm{mM}$ sucrose at $37^{\circ} \mathrm{C}$ (see Section 3.10). As a result, mutants with reduced $\mathrm{T}_{\mathrm{m}}$ values according to the Thermofluor assay also showed decreased thermostability in a traditional thermal inactivation study (Figure 7). We therefore conclude that Thermofluor can be used as a high-throughput tool to evaluate thermostability of levansucrases and their mutant variants. 
Figure 7. Thermal inactivation assay of purified wild-type Lsc3 and the mutant proteins Asp31Asn, Glu236Gln, Val248Ala, Thr302Met and Thr302Pro. After incubation of $5 \mu \mathrm{M}$ of a levansucrase in McIlvaine's buffer ( $\mathrm{pH}$ 6.0) at a selected temperature, its residual activity was measured according to release of glucose from $100 \mathrm{mM}$ sucrose [4]. The activity of a preparation kept at $20{ }^{\circ} \mathrm{C}$ was used as reference for $100 \%$ of activity. Inner panel shows $T_{m}$ values obtained by the Thermofluor assay. The mean values of at least two parallel experiments and respective standard deviations are shown.

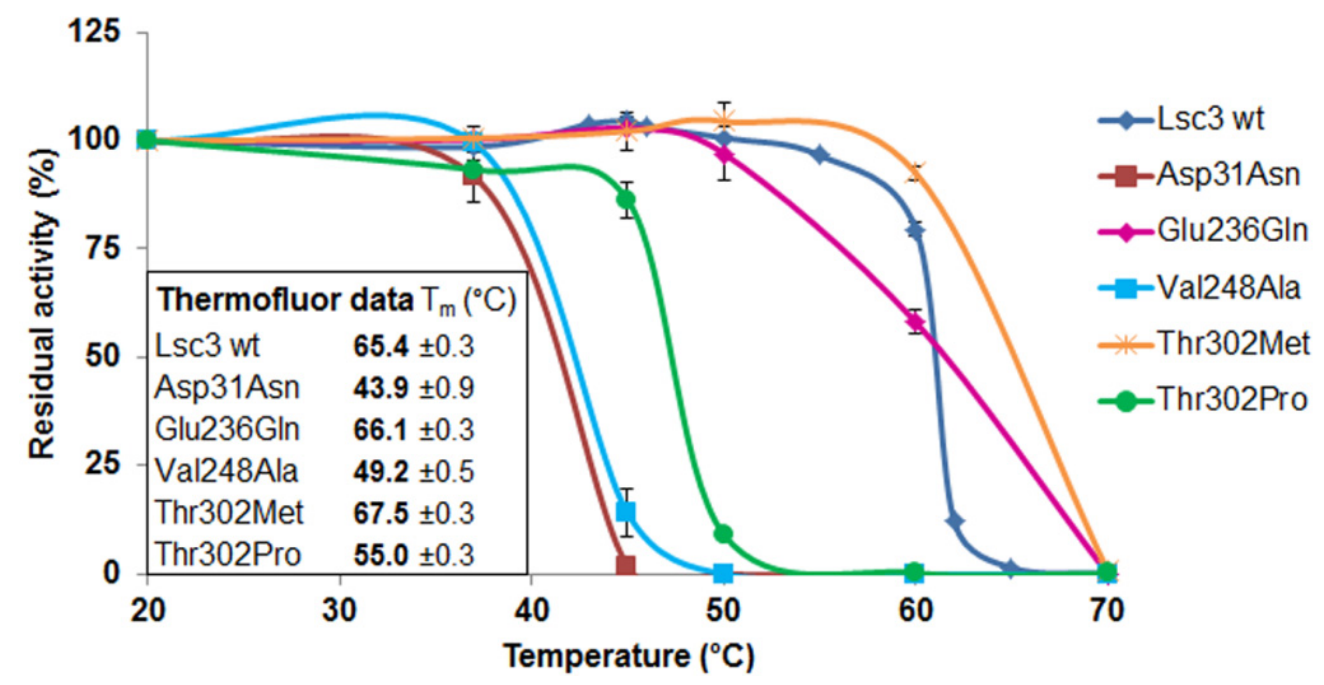

\subsection{Structure-Function Analysis of Novel Lsc3 Mutants}

In the current work we introduce fourteen novel mutants of the Lsc3 protein of $P$. syringae pv. tomato DC3000. Phenotype of these mutants will be discussed according to the location of mutated residue, starting from $\mathrm{N}$-terminus of the protein.

The Asp31Asn substitution originates from a random multiple mutant of Lsc3, MutG. E. coli expressing MutG from a plasmid had nonmucoid colonies on sucrose-containing agar medium. This mutant Lsc3 variant had four substitutions: Asp31Asn, Glu252Gly, Asp300Asn and Cys371Trp [21]. Based on MutG, two single mutants, Asp300Asn [21] and Asp31Asn were designed. Position corresponding to Asp31 is not strictly conserved-levansucrases of different bacteria and archaea have also His, Ala, Asn or Glu at this position (see Figure S2 in Supplementary materials). The Asp31Asn mutant has the lowest thermostability from mutants of the current work (Figure 7). It suggests that N-terminal domain of Lsc3 plays a role in the stability of the whole protein. The Asp31Asn substitution probably interferes with proper folding of the protein. According to crystal structure data of $G$. diazotrophicus and B. subtilis levansucrases, stable folding of levansucrases is provided through coordinated packing of N- and C-termini of the polypeptide. Similarly to B. subtilis levansucrase, the N-terminus of the $G$. diazotrophicus LsdA protein runs along the perimeter of blade IV forming a clamp-like loop that adds a fifth $\beta$-strand to blade III [5]. Notably, the amino acids of LsdA that comprise additional stabilizing $\beta$-strand to blade III are in close proximity of the "RADAL" motif [5] that harbours aspartate (underlined) corresponding to Asp31 of Lsc3.

The Trp109Arg mutant of Lsc3 is a counterpart of Trp109Arg mutant of Z. mobilis levansucrase, which displayed largely reduced levan synthesis [6]. We also made additional Trp109 substitutions 
with Ala and Phe. Figures 5 and 6 show that the Trp109Arg and Trp109Ala mutants display a drastic reduction of levan and FOS synthesis. Some levansucrases, such as the G. diazotrophicus LsdA (see Figure 1), have a Phe at the corresponding position. This explains why substitution of Trp109 with Phe restored the wild-type phenotype to Lsc3. Replacement of Trp109 with Phe even slightly enhanced levan synthesis (Figure 6). We hypothesize that Phe in this position slightly changes the architecture of catalytic centre causing the increase in donor and acceptor binding. Therefore fructan chains are elongated more efficiently. There is no evidence based on crystal structures of levansucrases that Trp or Phe in the respective position directly interact with the substrate [1,5]. To make further conclusions, additional evidence from crystal structures and data on product spectra of levansucrases and their mutants are needed. According to Betts and Russell [36], change of Trp to Phe is favoured in proteins, whereas change to Ala or Arg is not. We assume that Trp109 participates in forming of +2 subsite of the substrate-binding pocket of Lsc3 (see Figure 2). As sucrose-splitting activities of Trp109Arg and Trp109Ala mutants are also strongly reduced (Figures 4 and 5), Trp109 is probably also involved in binding of the substrate at +1 and/or -1 subsites or contributing to substrate cleavage reaction. This assumption is supported by the fact that the Trp109Arg mutant has strongly reduced affinity for sucrose - the $\mathrm{K}_{\mathrm{m}}$ is increased from 18.5 to $249 \mathrm{mM}$ (Table 1).

The Glu110Asp mutant was designed by us to study catalytic significance of a neighbouring position of Trp109. As shown in Figure 1, this position is not conserved in levansucrases. For example, respective residue in LsdA of $G$. diazotrophicus is Asp. Our data on the catalytic properties of Glu110Asp mutant shows no significant changes compared to the wild-type protein. Yet, velocity of levan synthesis was reduced and $\mathrm{K}_{\mathrm{m}}$ for sucrose was increased about by 3 times (Figure 6, Table 1). Importantly, when Glu110 was changed to Ala, the protein completely precipitated and could not be purified by $\mathrm{Ni}^{2+}$-affinity chromatography (data not shown) suggesting the importance of the position.

The His113Gln substitution was detected by us in a random double mutant (MutE) of Lsc3. This mutant carried an additional substitution, Val195Ile, and E. coli expressing this protein had nonmucoid colonies on a sucrose-containing agar plate. We chose to design the His113Gln mutant due to its proximity to a nucleophile Asp62 on the 3D model and a high conservation score. Figure 2 shows that homologues of His113 residue in levansucrases reside close to fructose residue (binds at -1 subsite) and galactose residue (binds at +2 subsite) of the raffinose molecule bound to the enzyme. Crystal structure of Arthrobacter sp. K-1 fructosyltransferase in complex with fructose (PDB: 3VSS; [37]) also shows that His147 in Arthrobacter sp. K-1 enzyme (a homologue of His113 of Lsc3) is at hydrogen-bondage distance from bound fructose. Notably, the Arthrobacter sp. K-1 enzyme is structurally similar to levansucrases [23,37]. To verify the importance of His113 in the catalysis, we additionally constructed the His113Ala mutant. Like His113Gln substitution, it had a very strong effect on sucrose-splitting reaction and levan synthesis (Figures 4 and 6). Notably, the Gln substitution had an even stronger negative effect on sucrose cleavage and FOS synthesis (Figure 5). We predict that His 113 participates in the binding of both fructosyl donor (at -1 subsite) and acceptor (at +2 subsite) to Lsc3. Importantly, this is the first report of catalytic importance of this position in levansucrases.

The Glu146Gln variant of Lsc3 was constructed to mimic the Glu117Gln mutant (see Figure 1) of Z. mobilis levansucrase. The Glu117Gln mutant had decreased affinity for sucrose and increased transfructosylating activity [6]. According to our results, the Glu146Gln mutant of Lsc3 displayed a two-fold increase in $\mathrm{K}_{\mathrm{m}}$ towards sucrose, whereas significantly enhanced transfructosylation was not 
detected (Table 1; Figure 6). Still, our assay showed that the Glu146Gln mutant produced more FOS per $\mathrm{mg}$ of protein than the wild-type Lsc3 (Figure 5), whereas levan production was reduced (Figure 6). Typically, levansucrases have a Glu at position corresponding to Glu146 of Lsc3, but the Arthrobacter sp. K-1 $\beta$-fructofuranosidase which has a high transfrucosylating activity, has a Gln [37]. We conclude that substitution of Glu146 in Lsc3 with Gln favours synthesis of FOS at the expense of levan.

The Glu236Gln mutant of Lsc3 corresponds to Glu211Gln mutant of Z. mobilis levansucrase which retained only $28 \%$ of hydrolyzing activity and $17 \%$ of transfructosylating activity of the wild-type protein [6]. The Glu236Gln mutant of Lsc3 showed decreased transfructosylation and ability to bind sucrose - the $\mathrm{K}_{\mathrm{m}}$ was increased 14.4-fold (see Table 1 and Figures 5 and 6). The position corresponding to Glu236 in Lsc3 is completely conserved among levansucrases (see Figures 1 and 2). In-depth analysis of crystal structures of B. subtilis levansucrase SacB complexed with substrates (PDB IDs: 1PT2 in complex with sucrose and 3BYN with raffinose [10,38]) revealed that Glu262 locates close to Arg246 of the RDP motif that participates in binding of the substrate at both the -1 and +1 subsites. According to both crystal structures, Glu262 forms hydrogen bonds with Arg246 and also with fructose and glucose residues of the substrate over a water molecule. We assume that Glu236 contributes to stabilization of the substrate in the active site.

The Val248Ala mutant of Lsc3 is a counterpart of Val223Ala mutant of Z. mobilis levansucrase that displayed a tenfold decrease of the $\mathrm{k}_{\text {cat }}$ whereas the TA value remained the same [6]. The $\mathrm{V}_{\max }$ of sucrose-splitting reaction of Val248Ala mutant of Lsc3 was 39\% of the wild-type level when measured at $37^{\circ} \mathrm{C}$ (Figure 5). However, the $\mathrm{T}_{\mathrm{m}}$ value of the Val248Ala mutant was 16 degrees lower than that of the wild-type enzyme and its reduced thermostability became also evident in a traditional thermal inactivation assay (Figure 7). We assume that Val248Ala substitution affects the folding of Lsc3 protein and thereby its stability and catalytic activity.

We have previously described the Asp300Asn mutant originating from random mutagenesis [21]. This substitution slightly reduces the affinity of the protein for sucrose. An interesting feature of the Asp300Asn mutant is the production of long-chain FOS, with DP up to 10, whereas the wild-type Lsc3 synthesizes FOS with DP up to 7 [21,23]. The Asp300Ala mutant addressed in the current work behaved similarly to wild-type Lsc3, producing FOS with DP up to 8 (Table 1). Thus, for a yet unknown reason, the presence of Asn at position 300 of Lsc3 promotes synthesis of long-chain FOS.

The Asp333Asn mutant of Lsc3 was constructed to mimic the Asp308Asn mutant of Z. mobilis levansucrase. The Asp308Asn mutant had slightly decreased transfructosylation ability and about four-fold decreased affinity for sucrose [6]. This position is highly conserved in levansucrases (Figure 1). Yet, in Arthrobacter sp. K1 enzyme, a Glu, and in B. subtilis SacB an Asn (Asn372) is found at the same position (Figure 1). Aside of making the Asp333Asn mutant, we also constructed respective Ala substitution variant. $\mathrm{V}_{\max }$ of sucrose-splitting reaction of the Asp333Ala mutant was four-fold lower compared to wild-type enzyme and levan synthesis was also significantly reduced. The Asp333Asn mutant behaved much more similarly to wild-type Lsc3 than the Asp333Ala (Figures 5 and 6). We suppose that Asp333 can be involved in substrate binding and elongation of the fructan chain. 


\section{Experimental}

\subsection{Construction of Levansucrase Mutants}

Mutant variants of levansucrase $l s c 3$ gene were constructed using primer-based site-specific mutation strategy as reported earlier [21,23]. Mutagenic oligonucleotides and respective amino acid replacements are listed in Table S1 of Supplementary materials. Cloning of the genes into the expression vector pURI3 [39] was performed as shown in [21,23]. Plasmid DNA was purified using FavorPrep $^{\mathrm{TM}}$ Plasmid Extraction Mini Kit (Favorgen Biotech Corp., Ping-Tung, Taiwan) and the mutations were verified by DNA sequencing.

\subsection{Cultivation of Bacteria and Purification of Recombinant Levansucrases}

Transformed E. coli was grown in LB broth containing ampicillin (Amp) $0.15 \mathrm{mg} / \mathrm{mL}$ at $37{ }^{\circ} \mathrm{C}$. Mutated and wild-type Lsc3 proteins were overexpressed in E. coli BL21(DE3) [40]. Purification of $\mathrm{N}$-terminally His-tagged proteins was performed as in [21]. For phenotypic evaluation of E. coli BL21(DE3) transformants expressing levansucrase variants, they were grown overnight at $37{ }^{\circ} \mathrm{C}$ on MacConkey + Amp medium containing 10\% sucrose and $1 \mathrm{mM}$ isopropyl $\beta$-D-1-thiogalactopyranoside (IPTG). The plates were further kept at room temperature $\left(23^{\circ} \mathrm{C}\right)$ until levan synthesis (slime production) and acid production (pink colour) from the sugar became evident.

\subsection{Permeabilization of E. coli Cells and Sucrose-Splitting Activity Assay of Levansucrases on}

\section{Permeabilized Bacteria}

The levansucrase-expressing transformants of $E$. coli BL21(DE3) were grown overnight in LB-Amp broth on a sterile 96-well flat-bottom transparent polystyrol microplate (CELLSTAR, Greiner Bio-One, Frickenhausen, Germany) at $37{ }^{\circ} \mathrm{C}$ on a shaker (900 rpm) with $200 \mu \mathrm{L}$ of the culture per well. Overnight cultures were diluted in LB-Amp broth to $\mathrm{OD}_{600} \mathrm{~nm}$ of $\sim 0.016$ (respective value measured in a $1 \mathrm{~cm}$ pathway cuvette is 0.05 ) and were further agitated on a shaker at $37^{\circ} \mathrm{C}$ for $2 \mathrm{~h}$. To induce levansucrase expression, IPTG was added to the wells (final concentration $0.5 \mathrm{mM}$ ) and the microplate was further incubated on a shaker at $22{ }^{\circ} \mathrm{C}$ for $20 \mathrm{~h}$. Then, $\mathrm{OD}_{600 \mathrm{~nm}}$ values of the cultures were measured and they were diluted approximately 10 times in McIllvaine's buffer ( $\mathrm{pH}$ 6.0) to obtain the $\mathrm{OD}_{600} \mathrm{~nm}$ value of approximately $\sim 0.067$ (respective value measured in a $1 \mathrm{~cm}$-pathway cuvette is 0.2 ). Undiluted culture was used in case of clones with severely reduced sucrose-splitting activity.

Next, the cells were permeabilized with $0.1 \%$ cetyltrimethylammonium bromide (CTAB). Briefly, $50 \mu \mathrm{L}$ of microplate-grown and appropriately diluted E. coli BL21(DE3) cultures were combined with $50 \mu \mathrm{L}$ of $0.2 \%$ CTAB solution in Mclllvaine's buffer ( $\mathrm{pH} 6.0$ ) in wells of a new microplate and agitated $(900 \mathrm{rpm})$ for $10 \mathrm{~min}$ at room temperature to permeabilize cellular membranes. Levansucrase reaction was then started by adding $50 \mu \mathrm{L}$ of $300 \mathrm{mM}$ sucrose (final concentration $100 \mathrm{mM}$ ) in McIllvaine's buffer ( $\mathrm{pH}$ 6.0). The reaction was conducted at $37{ }^{\circ} \mathrm{C}$ for $5 \mathrm{~min}$ and then stopped by transferring $10 \mu \mathrm{L}$ of the reaction mixture into a new well containing $30 \mu \mathrm{L}$ of Tris buffer $(200 \mathrm{mM}$, $\mathrm{pH} 8.3$ ), subsequently heated at $96{ }^{\circ} \mathrm{C}$ for $5 \mathrm{~min}$ and cooled on ice. Released glucose was visualized by adding $160 \mu \mathrm{L}$ of Glucose liquicolor reactive (Human $\mathrm{GmbH}$, Wiesbaden, Germany) and incubating the 
plate for $5 \mathrm{~min}$ at $37^{\circ} \mathrm{C}$. Absorbance of the reddish complex was measured at $500 \mathrm{~nm}$. All absorbance values were recorded using Infinite M200 PRO microplate reader (Tecan Group Ltd., Männedorf, Switzerland) equipped with Tecan i-control 1.7 software. E. coli culture BL21(DE3) carrying the empty pURI3 plasmid served as a negative control for the assay. The sucrose-splitting activity was expressed as percentage of the respective normalized activity of the wild-type Lsc3. To normalize the activities, $\mathrm{OD}_{600 \mathrm{~nm}}$ values of cell suspensions in the wells were measured. Correction coefficients for mutants were calculated by dividing the $\mathrm{OD}_{600 \mathrm{~nm}}$ value of the wild-type to the $\mathrm{OD}$ value of the respective mutant.

\subsection{Sucrose-Splitting Activity Assay on Microplates Using Purified Levansucrases}

To measure the sucrose-splitting activity of purified levansucrases, proteins were diluted in McIllvaine's buffer to contain $2 \mathrm{U} / \mathrm{mL}$ of the enzyme. Unit values were calculated from sucrose-splitting activity measurements with $100 \mathrm{mM}$ sucrose at $37^{\circ} \mathrm{C}$ [4,21]. Assay was conducted as in case of using permeabilized cells (see Section 3.3), but instead of cells, appropriately diluted purified proteins were used. $50 \mu \mathrm{L}$ of purified protein preparation (final concentration in reaction mixture $0.67 \mathrm{U} / \mathrm{mL}$; approximately $1.7 \mu \mathrm{g} / \mathrm{mL}$ in case of wild-type Lsc3) were combined with equal amount of McIllvaine's buffer ( $\mathrm{pH}$ 6.0). In case of mutants with extremely low sucrose-splitting activities, $10 \mu \mathrm{g}$ of protein per well $(66.7 \mu \mathrm{g} / \mathrm{mL})$ was used. The reaction was started by adding $50 \mu \mathrm{L}$ of $300 \mathrm{mM}$ sucrose (final concentration $100 \mathrm{mM}$ ) in McIllvaine's buffer and conducted for $5 \mathrm{~min}$ at $37{ }^{\circ} \mathrm{C}$. Stopping of the reaction and measurement of glucose content were performed as described above (see Section 3.3). Glucose released from sucrose was quantified from respective calibration curve. Activity unit expresses the amount of glucose in $\mu$ moles produced per min per mg of levansucrase protein (U/mg). Activity value obtained with wild-type Lsc3 was taken as $100 \%$.

\subsection{FOS-production Assay of Levansucrases Using Permeabilized E. coli}

Fifty $\mu \mathrm{L}$ of the levansucrase-expressing E. coli BL21(DE3) cultures were permeabilized as shown in Section 3.3. Then, $100 \mu \mathrm{L}$ of $2 \mathrm{M}$ sucrose (final concentration in a well $1 \mathrm{M}$ ) in McIllvaine's buffer were added, the plate was sealed firmly to avoid evaporation and incubated without agitation at $37^{\circ} \mathrm{C}$ for $20 \mathrm{~h}$. The reaction was stopped by heating the microplate for $5 \mathrm{~min}$ at $96^{\circ} \mathrm{C}$. For HPLC analysis of polymerization products, the reaction samples were transferred from the microplate to microtubes and centrifuged for $10 \mathrm{~min}$ at 16,000 g. The supernatants were withdrawn and further heated for $10 \mathrm{~min}$ at $96{ }^{\circ} \mathrm{C}$ to completely inactivate the levansucrase protein. Mono- and oligosaccharides in the samples were analysed using HPLC (Section 3.9). E. coli culture BL21(DE3) carrying the empty pURI3 plasmid served as negative control for the assay.

\subsection{FOS-production Assay of Levansucrases Using Purified Proteins}

The FOS-production assay was conducted as described in [23]. Purified proteins $(2.7 \mathrm{U} / \mathrm{mL})$ were incubated in Mclllvaine's buffer ( $\mathrm{pH}$ 6.0) containing $1.2 \mathrm{M}$ sucrose at $37^{\circ} \mathrm{C}$ for $20 \mathrm{~h}$. The reactions were conducted in Eppendorf tubes, the final volume of the reaction mixture was $1 \mathrm{~mL}$. In case of mutants with severely reduced catalytic activity (Trp61Ala, Trp61Asn, Asp62Ala, Trp109Arg, 
Asp219Ala, Arg304Cys, Glu303Ala, Glu303Gln), $100 \mu \mathrm{g} / \mathrm{mL}$ of purified protein was used in the reaction. The reaction was stopped by heating samples at $96{ }^{\circ} \mathrm{C}$ for $5 \mathrm{~min}$. Mono- and oligosaccharides in the samples were analysed using HPLC (Section 3.9).

\subsection{Levan Synthesis Assay of Levansucrases on Microplates Using Purified Proteins}

Kinetics of levan synthesis from sucrose by the purified Lsc3 variants was recorded on microplates using $10 \mu \mathrm{g} / \mathrm{mL}$ (the final concentration in reaction mixture) of purified protein. The proteins were diluted in McIlvaine's buffer ( $\mathrm{pH}$ 6.0) and incubated at $37{ }^{\circ} \mathrm{C}$ on transparent flat-bottom polystyrole microplates in a total volume of $200 \mu \mathrm{L}$ per well. The reaction was started by adding $2 \mathrm{M}$ sucrose in McIlvaine's buffer at final concentration 0.6 M. Microplates were incubated in Infinite M200 PRO microplate reader (Tecan Group Ltd.) at $37{ }^{\circ} \mathrm{C}$ and the turbidity $\left(\mathrm{OD}_{400} \mathrm{~nm}\right)$ values were recorded every 15 min during $12 \mathrm{~h}$.

\subsection{Determination of $V_{\max }, K_{m}$ for Sucrose and Transfructosylating Activity of Purified Proteins}

$\mathrm{K}_{\mathrm{m}}$ and $\mathrm{V}_{\max }$ of levansucrases were determined as reported previously [23]. For that, the initial velocities of sucrose-splitting reaction were determined at varied concentrations (from 5 to $1200 \mathrm{mM}$ ) of sucrose. Data was analysed using Enzyme Kinetics Module 1.1 of Sigma Plot 2001 (SYSTAT, San Jose, CA, USA). Protein concentration was determined by measuring the absorbance at $280 \mathrm{~nm}$. The extinction coefficients were computed at ExPASy Proteomics Server.

Transfructosylating activity (TA) was calculated as percentage of fructose residues from reacted sucrose molecules incorporated into polymerization products $[6,21,23]$.

\subsection{Quantification of Sugars by HPLC Analysis}

HPLC method was used to quantify glucose, fructose, sucrose and FOS content in the reaction mixtures $[23,41]$. Chromatography was performed on an Alltech Prevail Carbohydrate ES column (Grace, Deerfield, IL, USA) using Acquity UPLC system (Waters, Milford, MA, USA) coupled with evaporative light scattering (ELS) detector similarly as in [23]. The mobile phase consisted of LC-grade water (A) and acetonitrile (B). The gradient of solvent B was following: $70 \%-50 \% 15$ min; $50 \% 10 \mathrm{~min} ; 50 \%-70 \% 2 \mathrm{~min} ; 70 \% 13 \mathrm{~min}$ at flow rate of $0.6 \mathrm{~mL} / \mathrm{min}$. D-glucose (Oriola, Espoo, Finland), D-fructose (Sigma-Aldrich, St. Louis, MO, USA), sucrose (Serva, Heidelberg, Germany), raffinose (Naxo, Tartu, Estonia), 1-kestose (Sigma-Aldrich) and nystose (Sigma-Aldrich) were used as standards. Calibration curves were made using standard solutions with concentrations ranging from 0.1 to $5 \mathrm{mg} / \mathrm{mL}$. FOS in the range of degree of polymerization of 3-10 were calibrated against raffinose.

\subsection{Thermofluor Assay of Thermostability of Levansucrases and Levansucrase Activity Assay of Thermostability}

Thermal shift assay, also known as Thremofluor ${ }^{\circledR}$ [35], was performed using a LightCycler ${ }^{\circledR} 480$ System (Roche, Basel, Switzerland). Combined channels (465-580 nm) were selected as suitable for the measurements using SYPRO ${ }^{\circledR}$ Orange (Sigma-Aldrich) as a fluorescent dye. The samples (final amount $20 \mu \mathrm{L}$ ) contained $2 \mu \mathrm{M}$ of the protein and $5 \times$ SYPRO $^{\circledR}$ Orange in $100 \mathrm{mM}$ MES buffer 
(pH 6.5) with $150 \mathrm{mM} \mathrm{NaCl}$. Samples were pipetted onto a Roche white LightCycler ${ }^{\circledR} 480$ multiwell plate for 96 samples and sealed with the foil as recommended by the manufacturer. The plate was centrifuged at room temperature at $200 \mathrm{~g}$ for $30 \mathrm{~s}$ to remove the air bubbles.

Temperature gradient from 27 to $95{ }^{\circ} \mathrm{C}$ was applied and data was recorded using LightCycler ${ }^{\circledR} 480$ software (release 1.5.0 SP3). The melting temperature $\left(\mathrm{T}_{\mathrm{m}}\right)$, used here as a thermostability characteristic of levansucrases, is defined as temperature at which half of the protein in the studied sample is unfolded. The $\mathrm{T}_{\mathrm{m}}$ was specified as temperature at which the derivative curve apex had a minimum value. Mutants that differed significantly from the wild-type Lsc3 according to $T_{m}$ were selected for traditional thermostability assay to obtain data for comparison. Purified Lsc3 mutants Asp31Asn, Glu236Gln, Val248Ala, Thr302Met, Thr302Pro and the wild-type Lsc3 (5 $\mu \mathrm{M}$ of protein in McIlvaine's buffer; $\mathrm{pH}$ 6.0) were incubated at varied temperature (from 20 to $70{ }^{\circ} \mathrm{C}$ ) for 30 min and then cooled on ice. Residual total levansucrase activity of the samples was measured at $37{ }^{\circ} \mathrm{C}$ by quantifying the release of glucose from $100 \mathrm{mM}$ sucrose as in [4,21].

\section{Conclusions}

We conclude that cost-saving high-throughput methods are feasible for preliminary characterization of levansucrases and their mutant variants. Importantly, some features of levansucrases such as the sucrose-splitting activity and the ability to produce fructooligosaccharides, can be reliably evaluated on surfactant-treated recombinant Escherichia coli cells expressing the protein. Thermofluor method was used here for the first time to characterize thermostability of levansucrase mutants. Our current study provides new tools for the isolation, selection and characterization of levansucrases. These proteins are important as they can be used to synthesize $\beta$-2,6-linked fructooligosaccharides and levan, biological effects of which are yet poorly assayed compared with respective $\beta$-2,1-linked counterparts.

\section{Supplementary Materials}

Supplementary materials can be accessed at: http://www.mdpi.com/1420-3049/19/6/8434/s1.

\section{Acknowledgments}

This research was funded partially by Estonian Science Foundation grants 9072 and SF0180088s08. ERF grant 3.2.0701.12-0041 (SLOMR12215T) managed by the Archimedes Foundation covered open access publication costs and part of the experimental expenses. We thank D. Lubenets for his kind help in Thermofluor experiments.

\section{Author Contributions}

Designed and conceived the experiments: T.A., K.M., T.V., K.V. and H.V. Performed the experiments: K.M., T.V., H.V., M.G., A.A. Interpreted the data and wrote the paper: K.M., T.A., T.V., H.V., M.G., A.A. All the authors have read and approved the final manuscript.

\section{Conflicts of Interest}

The authors declare no conflict of interest. 


\section{References}

1. Lammens, W.; le Roy, K.; Schroeven, L.; van Laere, A.; Rabijns, A.; van den Ende, W. Structural insights into glycoside hydrolase family 32 and 68 enzymes: Functional implications. J. Exp. Bot. 2009, 60, 727-740.

2. Hettwer, U.; Gross, M.; Rudolph, K. Purification and characterization of an extracellular levansucrase from Pseudomonas syringae pv. phaseolicola. J. Bacteriol. 1995, 177, 2834-2839.

3. Li, H.; Ullrich, M. Characterization and mutational analysis of three allelic lsc genes encoding levansucrase in Pseudomonas syringae. J. Bacteriol. 2001, 183, 3282-3292.

4. Visnapuu, T.; Mäe, A.; Alamäe, T. Hansenula polymorpha maltase gene promoter with sigma 70-like elements is feasible for Escherichia coli-based biotechnological applications: Expression of three genomic levansucrase genes of Pseudomonas syringae pv. tomato. Process Biochem. 2008, 43, 414-422.

5. Martínez-Fleites, C.; Ortíz-Lombardía, M.; Pons, T.; Tarbouriech, N.; Taylor, E.J.; Hernández, L.; Davies, G.J. Crystal structure of levansucrase from the Gram-negative bacterium Gluconacetobacter diazotrophicus. Biochem. J. 2005, 390, 19-27.

6. Yanase, H.; Maeda, M.; Hagiwara, E.; Yagi, H.; Taniguchi, K.; Okamato, K. Identification of functionally important amino acid residues in Zymomonas mobilis levansucrase. J. Biochem. 2002, 132, 565-572.

7. Geier, G.; Geider, K. Characterization and influence on virulence of the levansucrase gene from the fireblight pathogen Erwinia amylovora. Physiol. Mol. Plant Pathol. 1993, 42, 387-404.

8. Caputi, L.; Cianci, M.; Benini, S. Cloning, expression, purification, crystallization and preliminary X-ray analysis of EaLsc, a levansucrase from Erwinia amylovora. Acta Crystallogr. 2013, F69, 570-573.

9. Caputi, L.; Nepogodiev, S.A.; Malnoy, M.; Rejzek, M.; Field, R.A.; Benini, S. Biomolecular characterization of the levansucrase of Erwinia amylovora, a promising biocatalyst for the synthesis of fructooligosaccharides. J. Agric. Food Chem. 2013, 61, 12265-12273.

10. Meng, G.; Fütterer, K. Structural framework of fructosyl transfer in Bacillus subtilis levansucrase. Nat. Struct. Biol. 2003, 10, 935-941.

11. Homann, A.; Biedendieck, R.; Götze, S.; Jahn, D.; Seibel, J. Insights into polymer versus oligosaccharide synthesis: Mutagenesis and mechanistic studies of a novel levansucrase from Bacillus megaterium. Biochem. J. 2007, 407, 189-198.

12. Van Geel-Schutten, G.H.; Faber, E.J.; Smit, E.; Bonting, K.; Smith, M.R.; Ten Brink, B.; Kamerling, J.P.; Vliegenthart, J.F.G.; Dijkhuizen, L. Biochemical and structural characterization of the glucan and fructan exopolysaccharides synthesized by the Lactobacillus reuteri wild-type strain and by mutant strains. Appl. Environ. Microbiol. 1999, 65, 3008-3014.

13. Korakli, M.; Pavlovic, M.; Gänzle, M.G.; Vogel, R.F. Exopolysaccharide and kestose production by Lactobacillus sanfranciscensis LTH2590. Appl. Environ. Microbiol. 2003, 69, 2073-2079.

14. Kang, H.K.; Seo, M.Y.; Seo, E.S.; Kim, D.; Chung, S.Y.; Kimura, A.; Day, D.F.; Robyt, J.F. Cloning and expression of levansucrase from Leuconostoc mesenteroides B-512 FMC in Escherichia coli. Biochim. Biophys. Acta 2005, 1727, 5-15. 
15. Gibson, G.R.; Scott, K.P.; Rastall, R.A.; Tuohy, K.M.; Hotchkiss, A.; Dubert-Ferrandon, A.; Gareau, M.; Murphy, E.F.; Saulnier, D.; Loh, G.; et al. Dietary prebiotics: Current status and new definition. IFIS Funct. Foods Bull. 2010, 7, 1-19.

16. Koropatkin, N.M.; Cameron, E.A.; Martens, E.C. How glycan metabolism shapes the human gut microbiota. Nat. Rev. Microbiol. 2012, 10, 323-335.

17. Marx, S.P.; Winkler, S.; Hartmeier, W. Metabolization of $\beta-(2,6)$-linked fructose-oligosaccharides by different bifidobacteria. FEMS Microbiol. Lett. 2000, 182, 163-169.

18. Kilian, S.; Kritzinger, S.; Rycroft, C.; Gibson, G.; du Preez, J. The effects of the novel bifidogenic trisaccharide, neokestose, on the human colonic microbiota. World J. Microbiol. Biotechnol. 2002, 18, 637-644.

19. Marsh, A.J.; O’Sullivan, O.; Hill, C.; Ross, R.P.; Cotter, P.D. Sequence-based analysis of the microbial composition of water kefir from multiple sources. FEMS Microbiol. Lett. 2013, 348, 79-85.

20. Alamäe, T.; Visnapuu, T.; Mardo, K.; Mäe, A.; Zamfir, A.D. Levansucrases of Pseudomonas bacteria: Novel approaches for protein expression, assay of enzymes, fructooligosaccharides and heterooligofructans. In Carbohydrate Chemistry, Specialist Periodical Reports; Rauter, A.P., Lindhorst, T.K., Eds.; Royal Society of Chemistry: Cambridge, UK, 2012; Volume 38, pp. 176-191.

21. Visnapuu, T.; Mardo, K.; Mosoarca, C.; Zamfir, A.D.; Vigants, A.; Alamäe T. Levansucrases from Pseudomonas syringae pv. tomato and P. chlororaphis subsp. aurantiaca: Substrate specificity, polymerizing properties and usage of different acceptors for fructosylation. J. Biotechnol. 2011, 155, 338-349.

22. Visnapuu, T.; Zamfir, A.D.; Mosoarca, C.; Stanescu, M.D.; Alamäe, T. Fully automated chip-based negative mode nanoelectrospray mass spectrometry of fructooligosaccharides produced by heterologously expressed levansucrase from Pseudomonas syringae pv. tomato DC3000. Rapid Commun. Mass Spectrom. 2009, 23, 1337-1346.

23. Mardo, K.; Visnapuu, T.; Vija, H.; Elmi, T.; Alamäe, T. Mutational analysis of conserved regions harboring catalytic triad residues of the levansucrase protein encoded by the $l s c-3$ gene (lsc3) of Pseudomonas syringae pv. tomato DC3000. Biotechnol. Appl. Biochem. 2014, 61, 11-22.

24. Geiser, M.; Cebe, R.; Drewello, D.; Schmitz, R. Integration of PCR fragments at any specific site within cloning vectors without the use of restriction enzymes and DNA ligase. Biotechniques 2001, 31, 88-92.

25. De las Rivas, B.; Curiel, J.A.; Mancheño, J.M.; Muñoz, R. Expression vectors for enzyme restriction- and ligation-independent cloning for producing recombinant His-fusion proteins. Biotechnol. Prog. 2007, 23, 680-686.

26. Edgar, R.C. MUSCLE: Multiple sequence alignment with high accuracy and high throughput. Nucleic Acids Res. 2004, 32, 1792-1797.

27. DeLano, W.L. The PyMOL Molecular Graphics System; DeLano Scientific: San Carlos, CA, USA, 2002.

28. Li, S.; Yan, Y.; Zhou, Z.; Yu, H.; Zhan, Y.; Zhang, W.; Chen, M.; Lu, W.; Ping, S.; Lin, M. Single amino acid residue changes in subsite -1 of levansucrase from Zymomonas mobilis 10232 strongly influence the enzyme activities and products. Mol. Biol. Rep. 2011, 38, 2437-2443.

29. Alamäe, T.; Järviste, A. Permeabilization of the methylotrophic yeast Pichia pinus for intracellular enzyme analysis: A quantitative study. J. Microbiol. Methods 1995, 22, 193-205. 
30. Suppi, S.; Michelson, T.; Viigand, K.; Alamäe, T. Repression vs. activation of MOX, FMD, MPP1 and MAL1 promoters by sugars in Hansenula polymorpha: The outcome depends on cell's ability to phosphorylate sugar. FEMS Yeast Res. 2013, 13, 219-232.

31. De Abreu, M.A.; Alvaro-Benito, M.; Plou, F.J.; Fernández-Lobato, M.; Alcalde, M. Screening $\beta$-fructofuranosidases mutant libraries to enhance the transglycosylation rates of $\beta-(2 \rightarrow 6)$ fructooligosaccharides. Comb. Chem. High Throughput Screen. 2011, 14, 730-738.

32. Hernandez, L.; Arrieta, J.; Menendez, C.; Vazquez, R.; Coego, A.; Suarez, V.; Selman, G.; Petit-Glatron, M.F.; Chambert, R. Isolation and enzymic properties of levansucrase secreted by Acetobacter diazotrophicus SRT4, a bacterium associated with sugar cane. Biochem. J. 1995, 309, 113-118.

33. Batista, F.R.; Hernández, L.; Fernández, J.R.; Arrieta, J.; Menéndez, C.; Gómez, R.; Támbara, Y.; Pons, T. Substitution of Asp-309 by Asn in the Arg-Asp-Pro (RDP) motif of Acetobacter diazotrophicus levansucrase affects sucrose hydrolysis, but not enzyme specificity. Biochem. J. 1999, 337, 503-506.

34. Tambara, Y.; Hormaza, J.V.; Perez, C.; Leon, A.; Arrieta, J.; Hernandez, L. Structural analysis and optimised production of fructo-oligosaccharides by levansucrase from Acetobacter diazotrophicus SRT4. Biotechnol. Lett. 1999, 21, 117-121.

35. Pantoliano, M.W.; Petrella, E.C.; Kwasnoski, J.D.; Lobanov, V.S.; Myslik, J.; Graf, E.; Carver, T.; Asel, E.; Springer, B.A.; Lane, P.; et al. High-density miniaturized thermal shift assays as a general strategy for drug discovery. J. Biomol. Screen. 2001, 6, 429-440.

36. Betts, M.J.; Russell, R.B. Amino acid properties and consequences of subsitutions. In Bioinformatics for Geneticists; Barnes, M.R., Gray, I.C., Eds.; John Wiley \& Sons, Ltd.: West Sussex, UK, 2003; pp. 289-316.

37. Tonozuka, T.; Tamaki, A.; Yokoi, G.; Miyazaki, T.; Ichikawa, M.; Nishikawa, A.; Ohta, Y.; Hidaka, Y.; Katayama, K.; Hatada, Y.; et al. Crystal structure of a lactosucrose-producing enzyme, Arthrobacter sp. K-1 $\beta$-fructofuranosidase. Enzyme Microb. Technol. 2012, 51, 359-365.

38. Meng, G.; Fütterer, K. Donor substrate recognition in the raffinose-bound E342A mutant of fructosyltransferase Bacillus subtilis levansucrase. BMC Struct. Biol. 2008, 8, doi:10.1186/14726807-8-16.

39. Curiel, J.A.; de las Rivas, B.; Mancheño, J.M.; Muñoz, R. The pURI family of expression vectors: A versatile set of ligation independent cloning plasmids for producing recombinant His-fusion proteins. Protein Expr. Purif. 2011, 76, 44-53.

40. Studier, F.W.; Moffatt, B.A. Use of bacteriophage T7 RNA polymerase to direct selective high-level expression of cloned genes. J. Mol. Biol. 1986, 189, 113-130.

41. Downes, K.; Terry, L.A. A new acetonitrile-free mobile phase method for LC-ELSD quantification of fructooligosaccharides in onion (Allium cepa L.). Talanta 2010, 82, 118-124.

Sample Availability: Samples are not available from the authors.

(C) 2014 by the authors; licensee MDPI, Basel, Switzerland. This article is an open access article distributed under the terms and conditions of the Creative Commons Attribution license (http://creativecommons.org/licenses/by/3.0/). 